\title{
VARIASI EKSTRAK ETANOL BIJI ALPUKAT (Persea americana Mill.) PADA GRANUL EFFERVECSENT SEBAGAI ANTIDIABETES
}

\author{
Herwin, Hendra Herman
}

Fakultas Farmasi, Universitas Muslim Indonesia, Makassar

Email : herwinfarmasi@gmail.com;hendra.herman@umi.ac.id

\begin{abstract}
This study aims to product the preparation effevecsent granule using variation of ethanol extract avocado seed (Persea americana Mill.) as antidiabetic using granulation method. This study was conducted using two formulas using variation of ethanol extract avocado seed (Persea americana Mill.) 1\% and 10\%, PVP K30 4\%, Sodium cyclamate $0.1 \%$, citric acid 0.2965 gram, tartric acid $0.5931 \mathrm{gram}$ and sodium bicarbonate $1.0083 \mathrm{gram}$. The test results of evaluation preparation effevecsent granule using variation of ethanol extract avocado seed (Persea americana Mill.) showing that formulas 2 (two) is the best the result farmaceutic evaluation obtained with value Densitas Bulk $=2.82$, Incompressible Density $=0.353$, Carr's Indeks $=17.12$, Silent Angle $=19.79^{\circ}$, Flow Time $=0.7$, Time of Stopping Foam $=1.15$. The test results of antidiabetic at in vivo formulas 2 (two) preparation effevecsent granule of ethanol extract avocado seed (Persea americana Mill.) using male mice (Mus musculus) with weight $176.5 \mathrm{mg}$, Initial Glucose Level = 87.5, Initial Glucose Induction $=249.5$ obtained time of giving theraphy of formula at first day $=248.5$, second day $=133$, five day $=109$ and seven day $=75.5$, so preparation effevecsent granule of ethanol extract avocado seed (Persea americana Mill.) effective as antidiabetic.
\end{abstract}

Key words : Ethanol extract avocado seed, praparation effevecsent granule, antidiabetic.

\section{PENDAHULUAN}

Diabetes melitus merupakan suatu penyakit atau gangguan metabolisme kronis yang ditandai dengan tingginya kadar gula darah disertai dengan gangguan metabolisme karbohidrat, lipid dan protein sebagai akibat insufisiensi fungsi insulin. Ada empat jenis diabetes melitus, yaitu diabetes melitus tipe 1 , diabetes mellitus tipe 2, diabetes gestasional dan diabetes tipe spesifik lainnya. ${ }^{1}$ Berdasarkan data yang diterbitkan dalam jurnal Diabetes Care, penderita diabetes di Indonesia pada tahun 2000 mencapai 8,4 juta orang dan menduduki peringkat ke-4 setelah India, Tiongkok, dan Amerika Serikat. $^{2}$ Menurut data tersebut akan terjadi peningkatan drastis penderita diabetes yang terus-menerus pada tahun-tahun selanjutnya. Jumlah penderita diabetes yang semakin meningkat ini menyebabkan adanya peningkatan penggunaan obat antidiabetes. Adanya penggunaan obat-obat modern banyak diantaranya yang memicu adanya efek samping dan banyak pula yang telah resisten akibat penggunaan obat-obat modern sehingga diperlukan adanya pencarian obat herbal tradisional sebagai alternatif pengobatan diabetes mellitus.

Diabetes mellitus (DM) didefinisikan sebagai suatu penyakit atau gangguan metabolisme kronis dengan multi etiologi yang ditandai dengan tingginya kadar gula darah disertai dengan gangguan metabolisme karbohidrat, lipid dan protein sebagai akibat insufisiensi fungsi insulin. Insufisiensi fungsi insulin dapat disebabkan oleh gangguan atau defisiensi produksi insulin oleh sel-sel beta Langerhans kelenjar pankreas, atau 
Variasi ekstrak etanol biji alpukat (Persea americana Mill.) pada granul effervecsent sebagai antidiabetes

disebabkan oleh kurang responsifnya sel-sel tubuh terhadap insulin. ${ }^{3}$

WHO pun telah beberapa kali mengajukan klasifikasi diabetes melitus. Pada tahun 1965 WHO mengajukan beberapa istilah dalam pengklasifikasian diabetes, antara lain Childhood Diabetics, Young Diabetics, Adult Diabetics dan Elderly Diabetics. Pada tahun 1980 WHO mengemukakan klasifikasi baru diabetes melitus memperkuat rekomendasi National Diabetes Data Group pada tahun 1979 yang mengajukan 2 tipe utama diabetes melitus, yaitu "Insulin Dependent Diabetes Mellitus" (IDDM) disebut juga Diabetes Melitus Tipe 1 dan "Non-Insulin-Dependent Diabetes Mellitus" (NIDDM) yang disebut juga Diabetes Melitus Tipe $2{ }^{4}$

Pada diabetes melitus terdapat kekurangan relatif atau absolut insulin, yang menyebabkan penurunan ambila glukosa oleh jaringanyang sensiif terhadap insulin dan hal tersebut mempunyai konsekuensi yang serius. Lipolisis dan proteolisis otot menyebabkan berat badan dan kelemahan. Kadar asam KoA dihasilkan dalam hati dan biubah menjadi asam asetoasetat yang kemudian mengalami reduksi menjadi asam beta-hidroksibutiratatau mengalami dekarboksilasi menjadi aseton. ${ }^{5}$

Salah satu obat herbal/tradisional yang bermanfaat sebagai antidiabetes adalah tanaman Alpukat (Persea Americana Mill) yang secara empiris, bagian tanaman alpukat yang banyak dimanfaatkan adalah buahnya sebagai makanan buah segar. Selain itu pemanfaatan daging buah alpukat yang biasadilakukan masyarakat Eropa adalah digunakan sebagai bahan pangan yang diolahdalam berbagai masakan. Manfaat lain dari daging buah alpukat adalah untuk bahandasar kosmetik. Bagian lain yang dapat dimanfaatkan adalah daunnya yang muda sebagai obat tradisional (obat batu ginjal, rematik). ${ }^{6}$

Dengan adanya efektivitas biji alpukat tersebut sebagai penurun kadar glukosa darah, maka sangat diperlukan pembuatan sediaan obat dari biji alpukat dalam bentuk sediaan granul effervescent sehingga pemanfaatan biji alpukat di masyarakat dapat lebih dipertanggungjawabkan.

\section{METODE PENELITIAN}

\section{Tempat Dan Waktu Penelitian}

Penelitian dilakukan selama 5 (lima) bulan dan di mulai pada bulan November 2017 sampai bulan Maret 2018. Penelitian ini dilakukan di Laboratorium Fitokimia, Laboratorium Farmaseutika dan Laboratorium Farmakologi Fakultas Farmasi Universitas Muslim Indonesia.

\section{Alat Dan Bahan Penelitian}

Peralatan yang digunakan terdiri dari penggiling simpliisia (blender), neraca analitik, rotary evaporator, timbangan hewan, tabung ependorf, restrainer, pisau bedah, sentrifugator, stopwatch, mikropipet, spektrofotometer, Oven pengering, lemari pendingin, dan kandang non metabolik. Bahan baku yang digunakan adalah biji alpukat yang diekstraksi dengan metode dingin (maserasi). Dan bahan-bahan yang diperlukan dalam pengujian efek sediaan granul adalah mencit penderita diabetes mellitus, aloksan, kloroform, sekam, dan ransum standar.

\section{Prosedur Penelitian}

\section{Ekstraksi Biji Alpukat Dengan Metode Dingin (Maserasi)}

Biji alpukat diperoleh dari buah alpukat matang yang segar dan tidak cacat fisik asal Makassar. Biji alpukat dipisahkan 
Variasi ekstrak etanol biji alpukat (Persea americana Mill.) pada granul effervecsent sebagai antidiabetes

dari daging buah, dicuci hingga bersih lalu dipotong-potong kecil dan dikeringkan menggunakan oven pada suhu $40-60^{\circ} \mathrm{C}$ selama 2-5 jam. Biji alpukat kering dirajang dan dihaluskan menjadi serbuk menggunkan blender. Serbuk biji alpukat diekstraksi dengan metode dingin (maserasi) dengan cara sebanyak enam ratus (600) gram serbuk biji alpukat direndam dengan 6 liter etanol 96\% dalam bejana maserasi selama 3 hari dalam suhu ruangan yang terlindung dari cahaya matahari. Kemudian maserat disaring dengan corong Buchner yang dilapisi kertas saring dan diuapkan dengan rotavapor pada suhu sehingga diperoleh ekstrak etanol biji alpukat.

Formulasi Ekstrak Biji Alpukat Sebagai

\section{Sediaan Granul Effervescent}

Ekstrak etanol biji alpukat diformulasi sebagai sediaan granul effervescent dengan 2 (dua) rancangan formula yaitu formula 1 dan 2 dibuat variasi kosentrasi ekstrak biji alpukat yaitu $1 \%$, dan $10 \%$ kemudian dilakukan penambahan laktosa $(0,75 \mathrm{~g})$, natrium bikarbonat, asam sitrat, asam tartrat dan laktosa. Laktosa dan ekstrak di triturasi di dalam mortar hingga homogen. Asam tartarat, natrium bikarbonat dan asam sitrat masingmasing di gerus hingga menghasilkan partikel yang halus, kemudian dimasukkan kedalam campuran laktosa dan ekstrak kemudian dicampur hingga homogen. Larutan PVP K30 $2 \%(b / v)$ dimasukkan kedalam campuran serbuk sedikit demi sedikit dan di ayak basah dengan menggunakan mesh 16. Granul basah kemudian dikeringkan dalam oven pada suhu $50^{\circ} \mathrm{C}$ selama 24 jam. Granul yang telah kering kemudian di ayak menggunakan mesh 10 dan dilakukan evaluasi sifat fisika granul. Hal yang sama di lakukan untuk formula 2.

\section{Evaluasi/Analisis Sediaan Granul Effervescent Secara Farmaseutika}

Hasil produksi sediaan granul effervescent biji alpukat dievaluasi atau dianalisis secara farmaseutika berdasarkan parameter pengujian organoleptik yaitu :

Densitas Bulk: Sebanyak 50,0 g granul effervescent dimasukkan kedalam gelas ukur $50 \mathrm{~mL}$ tanpa di mampatkan.. Serbuk kemudian di ukur volume densitas nyata, Vo.. Densitas bulk dihitung dengan menggunakan formula berikut : $\mathbf{\rho b}=\mathbf{M} /$ Vo. Keterangan: $\boldsymbol{\rho b}$ = Densitas bulk nyata, $\mathrm{M}=$ Berat sampel, $\mathrm{V}=$ volume nyata serbuk.

1. Densitas Mampat: Setelah mengukur densitas bulk, sampel kemudian di mampatkan sebanyak 500 kali diikuti dengan pemampatan tambahan sebanyak 750 kali hingga perbedaan antara pengukuran kurang dari $2 \%$ dan kemudian volume dimampatkan $\mathrm{Vf}$, diukur. Densitas mampat dihitung dalam $\mathrm{gr} / \mathrm{mL}$ menggunakan formula berikut : ptap $=\mathbf{M} /$ Vf. Keterangan: ptap = densitas mampat, $\mathrm{M}=$ berat sampel, $\mathrm{Vf}=$ volume serbuk yang dimampatkan.

2. Carr's Indeks (\%): Indeks kompresibilitas (Carr's index) adalah pengukuran propensitas serbuk untuk di kempa. Indeks kompresibilitas ditentukan dari densitas bulk dan densitas mampat. Dalam teori, semakin kurang kemampuan dapat dikempanya suatu bahan semakin dapat mengalir bahan tersebut. Pengukuran tersebut, menunjukkan pentingnya interaksi antarpartikel. Pada serbuk yang bebas mengalir, interaksi tersebut pada umumnya kurang signifikan, dan densitas bulk dan mampat akan lebih dekat dengan nilai. Untuk 
Variasi ekstrak etanol biji alpukat (Persea americana Mill.) pada granul effervecsent sebagai antidiabetes

serbuk yang sukar mengalir, interaksi antarpartikelnya yang besar, dan perbedaan yang besar antara densitas bulk dan mampat kemudian diamati. Perbedaan ini direfleksikan dalam Carr's Index yang dihitung menggunakan formula berikut: Indeks Kompresibilitas $=[(\rho t a p-\rho b) / \rho t a p] / \times 100$.

Hausner's ratio merupakan indeks tidak langsung dari kemudahan suatu serbuk mengalir. Hausner's ratio dihitung dengan menggunakan formula :

Hausner's Ratio = Densitas mampat (pt) /Densitas Bulk ( $\rho b)$.

3. Uji Sudut Diam: Metode fixed funnel digunakan untuk mengukur sudut diam. Corong pasang pada ketinggian tertentu (h) diatas kertas grafik yang ditempatkan pada permukaan horizontal yang datar. Serbuk secara hati-hati di tuang kedalam corong yang telah ditutupi bagian ujung corong hingga menyentuh ujung corong. Bagian bawah corong yang di tutupi dibuka untuk membiarkan granul turun ke atas kertas grafik. Radius dari dasar gundukan kerucut diukur. Sudut diam $(\theta)$ dihitung menggunakan formula berikut : $\operatorname{Tan} \boldsymbol{\theta}=\mathbf{h} / \mathbf{r}$. Keterangan: $\theta=$ Sudut Diam, $\mathrm{h}=$ Ketinggian kerucut, $\mathrm{r}=$ Radius dari dasar kerucut

\section{Waktu Penghentian Buih (Effervescent)}

Sebanyak $100 \mathrm{ml}$ air suling dimasukkan dalam beaker $250 \mathrm{~mL}$, satu dosis granul effervescent di tuang kedalam beaker, waktu berhentinya buih and waktu dihasilkan buih di amati.

Pengujian Dan Analisis Sediaan Granul Effervescent Sebagai Penurun Kadar Glukosa Darah Pada Mencit (Mus musculus)

\section{Pembuatan ekstrak uji}

Ekstrak yang telah didapatkan dibuat dalam tiga variasi konsentrasi. Ekstrak ditimbang sebanyak $0,05 \mathrm{~g}$, dan $0,5 \mathrm{~g}$ yang masing-masing mewakili konsentrasi $1 \%$ dan $10 \%$. Ekstrak yang telah ditimbang masingmasing dilarutkan dalam $5 \mathrm{~mL} \mathrm{Na.CMC} \mathrm{dan}$ dihomogenkan.

\section{Pembuatan suspensi Glucobay (Acarbose)}

Sebanyak 81,93 mg Acarbose digerus dari 10 tablet yang setara dengan $50 \mathrm{mg}$ Acarbose dan kemudian dilarutkan dalam 50 $\mathrm{mL} \mathrm{Na}$. CMC.

\section{Pembuatan larutan Aloksan}

Sebanyak $72 \mathrm{mg}$ aloksan ditimbang dan dilarutkan dalam $10 \mathrm{~mL} \mathrm{NaCl}$ steril 0,9\%. Larutan dihomogenkan di dalam vial yang terbungkus aluminium foil.

\section{Perlakuan Hewan Uji}

Untuk melihat efek pemberian granul effervecsent biji alpukat terhadap penurunan kadar glukosa hewan uji maka sebanyak 8 ekor mencit dibagi menjadi 2 kelompok terdiri dari 2 ekor mencit tiap kelompok. Setelah masa adaptasi \pm 2 minggu, semua kelompok hewan uji dipuasakan selama 12-16 jam untuk pengambilan kadar glukosa darah awal. Setelah itu, mencit diinduksi aloksan secara intraperitoneal. Aloksan bekerja selama 2×24 jam maka pengukuran kadar glukosanya dilakukan pada hari ke-3 setelah penginduksian. Setelah pengukuran kadar glukosa mencapai $\geq 200 \mathrm{mg} / \mathrm{dL}$, maka hewan uji siap diinduksi granul effervecsent. Kelompok A diberi perlakuan granul effervecsent $1 \%$, kelompok $B$ diberi perlakuan granul effervecsent $10 \%$, kelompok $\mathrm{C}$ diberi perlakuan obat Acarbose, dan kelompok $D$ sebagai kelompok aloksan (kontrol negatif). Semua perlakuan di atas diberikan secara 
Variasi ekstrak etanol biji alpukat (Persea americana Mill.) pada granul effervecsent sebagai antidiabetes

peroral. Perlakuan dilakukan selama 7 hari sesuai kelompom masing-masing. Kemudian diukur glukosa darah mencit pada hari pertama hingga hari ketujuh dengan tetap memberi perlakuan untuk setiap kelompoknya.

\section{Pengukuran kadar glukosa darah}

Pengukuran kadar glukosa darah dilakukan dengan cara diambil darah melalui ujung ekor dan darah diambil pada tetesan ketiga, kemudian diteteskan pada strip glucometer dan secara otomatis akan terbaca pada layar monitor glucometer.

\section{Pemeriksaan Histopatologi}

Hewan uji di yang dipilih mewakili setiap kelompok dimasukkan ke dalam toples berisi kapas yang telah dibasahi dengan kloroform. Setelah 5 menit, mencit yang tidak sadarkan diri kemudian dibedah dengan memotong kulit perut hingga terlihat isi perut untuk pemeriksaan jaringan dan organ. Setelah diamati, organ hewan uji diangkat, kemudian dibersihkan dengan larutan $\mathrm{NaCl}$ 0,9\% dan dimasukkan ke dalam pot berisi kloroform 10\%.

\section{HASIL DAN PEMBAHASAN}

\section{Hasil Ekstraksi Biji Alpukat Dengan Metode} Maserasi

Biji alpukat diperoleh dari buah alpukat matang yang segar dan tidak cacat fisik asal Makassar ditimbang sebanyak 575.6 gram. Biji alpukat dipisahkan dari daging buah, dicuci hingga bersih lalu dipotong-potong kecil dan dikeringkan menggunakan oven pada suhu $40-60^{\circ} \mathrm{C}$ selama $2-5$ jam diperoleh berat sampel kering 498 gram dengan kadar air sebesar $13.5 \%$, terlihat pada tabel 1 .

Tabel 1. Hasil Ekstraksi Biji Alpukat Secara Maserasi

\begin{tabular}{ccc}
\hline Berat Sampel Basah (gram) & Berat Sampel Kering (gram) & Kadar Air (\%) \\
\hline 575.6 & 498 & 13.5
\end{tabular}

\section{Hasil Fermulasi Sediaan Effervecsent}

Ekstrak biji alpukat diformulasi sebagai sediaan effervecsent dengan 2 komposisi formula yaitu ekstrak biji alpukat formula $1=$
$1 \%$ dan formula $2=10 \%$, PVP $\mathrm{K} 30=4 \%$, Natrium Siklamat $=0.1 \%$, Asam Sitrat $=$ 0.2965 gram, Asam Tartrat $=0.5931$ gram, Natrium Bikarbonat $=1.0083$ gram

\section{Hasil Evaluasi Sediaan granul Effervescent Ekstrak Biji Alpukat}

Tabel 2. Hasil penelitian kerapatan bulk granul effervescent ekstrak biji alpukat

\begin{tabular}{cccc}
\hline Formula & Berat $(\mathbf{g})$ & Volume $(\mathbf{m L})$ & Density $(\mathbf{g} / \mathbf{m L})$ \\
\hline 1 & 87.52 & 50 & 2.10 \\
2 & 82.61 & 50 & 2.82 \\
\hline
\end{tabular}

Tabel 3. Hasil penelitian kerapatan mampat granul effervescent ekstrak biji alpukat

\begin{tabular}{cccc}
\hline Formula & Berat $(\mathbf{g})$ & Volume $(\mathbf{m L})$ & Kerapatan $(\mathbf{g} / \mathbf{m L})$ \\
\hline 1 & 87.52 & 50 & 0,345 \\
2 & 82.61 & 50 & 0,353 \\
\hline
\end{tabular}

Tabel 4. Hasil penelitian indeks kompresibilitas granul effervescent ekstrak biji alpukat

\begin{tabular}{cccc}
\hline Formula & Volume bulk $(\mathbf{m L})$ & Volume mampat $(\mathbf{m L})$ & Indeks kompresibilitas (\%) \\
\hline 1 & 36.45 & 26.3 & 14,51 \\
2 & 13.55 & 26.5 & 17,12 \\
\hline
\end{tabular}


Variasi ekstrak etanol biji alpukat (Persea americana Mill.) pada granul effervecsent sebagai antidiabetes

Tabel 5. Hasil perhitungan Hausner's ratio granul effervescent ekstrak biji alpukat

\begin{tabular}{cccc}
\hline Formula & Bulk Volume $(\mathrm{mL})$ & Tapped volume $(\mathbf{m L})$ & Hausner's Ratio \\
\hline 1 & 36.45 & 35.2 & 0.82 \\
2 & 13.55 & 35.8 & 0.86 \\
\hline
\end{tabular}

Tabel 6. Hasil penelitian uji sudut diam granul effervescent ekstrak biji alpukat

\begin{tabular}{cccc}
\hline Formula & Diameter $(\mathbf{c m})$ & Tinggi $(\mathbf{c m})$ & Sudut Diam \\
\hline 1 & 10.20 & 2,8 & $15.35^{\circ}$ \\
2 & 10.55 & 3.8 & $19.79^{\circ}$ \\
\hline
\end{tabular}

Tabel 7. Hasil pengujian waktu alir dan kecepatan alir granul effervescent ekstrak biji alpukat

\begin{tabular}{cccc}
\hline Formula & Berat $\mathbf{( g )}$ & Waktu alir (detik) & Kecepatan alir (g/detik) \\
\hline 1 & 10.2 & 2,8 & 0.7 \\
2 & 10.5 & 3.8 & 0.7 \\
\hline
\end{tabular}

Tabel 8. Hasil penelitian uji waktu henti buih granul effervescent ekstrak biji alpukat

\begin{tabular}{ccc}
\hline Formula & Berat $\mathbf{( g )}$ & Waktu berhenti buih (detik) \\
\hline 1 & 87.52 & 52 \\
2 & 82.61 & 1.15 \\
\hline
\end{tabular}

Pembuatan granul effervescent ditujukan untuk menutupi rasa ekstrak dan meningatkan penggunaan daun sebagai suatu sediaan yang dapat dikonsumsi oleh pasien dengan segala usia. Bahan yang digunakan sebagai basis effervescent yaitu asam sitrat dan asam tartarat dapat menutupi rasa ektrak disebabkan karena kedua asam tersebut merupakan asam-asam buah. Menurut Farmakope Eropa edisi 6, bentuk effervescent di defenisikan sebagai "granul atau tablet untuk dilarutkan di dalam air sebelum pemberian pada pasien". Granul effervescent tidak disalut dan pada umumnya mengandung bahan asam dan bikarbonat yang bereaksi dengan cepat untuk melepaskan karbondioksida sekali granul melarut di dalam air. $^{7}$ Bentuk effervescent memiliki keuntungan disbanding dengan bentuk sediaan farmaseutik konvensional lainnya. Bentuk effervescent mengganti bentuk sediaan cair ketika bahan aktif memiliki stabilitas yang tidak memadai dalam bentuk cair karena bentuk effervescent dapat diberikan hanya pada saat sebelum di larutkan di dalam air. Bahan aktif yang tidak stabil dalam bentuk sediaan cair lebih stabil dalam bentuk effervescent. Bentuk sediaan ini mudah diberikan, khususnya pada pasien seperti anak-anak yang tidak dapat menelan kapsul atau tablet. rasa yang enak, karena karbonasi, membantu menutupi rasa obat yang tidak enak dari obat tertentu. Hal tersebut dapat membantu menghindari efek samping pada lambung dari obat tertentu. Mudah digunakan dan menarik pada konsumen karena warna dan penampakkan gelembung dibanding dengan bentuk sediaan tradisional. ${ }^{7}$

Granul adalah partikel yang memiliki ukuran sekitar mesh 4-10. Granul pada umumnya dibuat dengan mencampurkan bahan serbuk secara bersamaan dan kemjudian dilembabkan untuk membentuk massa mirip pasta. Massa yang terbentuk kemudian diayak dan kemudian dikeringkan di udara ataupun di oven. Formulasi granul effervescent menggunakan asam sitrat monohidrat dan asam tartarat dengan 
Variasi ekstrak etanol biji alpukat (Persea americana Mill.) pada granul effervecsent sebagai antidiabetes

perbandingan 1:2 menghasilkan serbuk dengan sifat effervescent yang baik. Kombinasi asam sitrat dan asam tartarat di lakukan karena penggunaan asam sitrat monohidrat tunggal akan menghasilkan campuran yang lengket yang tidak mudah digranulasi. Sedangkan penggunaan asam tartarat tunggal dapat menghasilkan granul yang terlalu rapuh dan mudah pecah.

Effervescence adalah pengeluaran gelembung gas dari suatu cairan, sebagai hasil dari reaksi kimia. Reaksi yang paling umum untuk tujuan farmaseutik adalah reaksi asam-basa antara natrium bikarbonat dan asam sitrat. ${ }^{7}$ Perbandingan asam sitrat:asam tartarat:natrium bikarbonat adalah $1: 2: 3: 4$ adalah sebagai berikut. ${ }^{9}$ Untuk meningkatkan rasa, natrium bikarbonat dikurangi menjadi 3,4 gram untuk membiarkan sedikit asan tidak bereaksi untuk menghasilkan rasa tajam (asam). Metode pembuatan granul effervescent menggunakan metode granulasi. Metode granulasi ini memiliki keuntungan yaitu homogenitas ekstrak lebih homogen dibandingkan dengan metode granulasi yang lain. Warna granul yang dihasilkan berwarna karamel. Setelah diperoleh granul effervescent maka dilakukan evaluasi fisika granul untuk mengetahui sifat fisika dan sifat granul.

Tabel 9. Hasil Pengukuran Kadar Glukosa Darah Pada Mencit (Mus musculus)

\begin{tabular}{|c|c|c|c|c|c|c|c|c|}
\hline \multirow{2}{*}{$\begin{array}{c}\text { Sampel } \\
\text { Uji }\end{array}$} & \multirow{2}{*}{ Replikasi } & \multirow{2}{*}{$\begin{array}{l}\text { Berat } \\
\text { Badan } \\
\text { (gram) }\end{array}$} & \multirow{2}{*}{$\begin{array}{c}\text { Glukosa } \\
\text { Darah awal } \\
(\mathrm{mg} / \mathrm{dL})\end{array}$} & \multirow{2}{*}{$\begin{array}{c}\text { Glukosa } \\
\text { Darah induksi } \\
(\mathrm{mg} / \mathrm{dL})\end{array}$} & \multicolumn{4}{|c|}{$\begin{array}{c}\text { Glukosa Darah Terapi (mg/dL) } \\
\text { (Hari Ke-) }\end{array}$} \\
\hline & & & & & 1 & 3 & 5 & 7 \\
\hline \multirow{3}{*}{$\begin{array}{c}\text { Ekstrak } \\
1 \%\end{array}$} & 1 & 175 & 89 & 259 & 234 & 112 & 81 & 76 \\
\hline & 2 & 178 & 86 & 240 & 269 & 154 & 137 & 75 \\
\hline & Rata-Rata & 176.5 & 87.5 & 249.5 & 248.5 & 133 & 109 & 75.5 \\
\hline \multirow{3}{*}{$\begin{array}{c}\text { Ekstrak } \\
10 \%\end{array}$} & 1 & 180 & 78 & 289 & 201 & 178 & 165 & 120 \\
\hline & 2 & 178 & 82 & 299 & 220 & 179 & 149 & 115 \\
\hline & Rata-Rata & 179 & 80 & 294 & 210.5 & 178.5 & 157 & 117.5 \\
\hline \multirow{3}{*}{ Akarbose } & 1 & 185 & 81 & 370 & 318 & 279 & 175 & 69 \\
\hline & 2 & 177 & 85 & 389 & 310 & 156 & 107 & 65 \\
\hline & Rata-Rata & 181 & 83 & 579.5 & 314 & 217.5 & 165.5 & 67 \\
\hline \multirow{3}{*}{$\begin{array}{l}\text { Kontrol } \\
\text { Negatif }\end{array}$} & 1 & 176 & 75 & 202 & 250 & 352 & 365 & 375 \\
\hline & 2 & 174 & 82 & 230 & 240 & 379 & 357 & 378 \\
\hline & Rata-Rata & 175 & 78.5 & 216 & 245 & 365.5 & 361 & 376.5 \\
\hline
\end{tabular}

1. Densitas bulk dan densitas mampat

Densitas di defenisikan sebagai berat per unit volume. Densitas bulk $\rho b$, di defenisikan sebagai berat serbuk dibagi dengan volume bulk dan dinyatakan sebagai $\mathrm{g} / \mathrm{cm}$. densitas bulk terutama bergantung pada distribusi ukuran partikel, bentuk partikel dan kecenderungan partikel untuk melekat satu sama lain. Densitas bulk sangat penting dalam hal yang berkaitan dengan ukuran wadah yang diperlukan untuk penanganan, pengapalan, dan penyimpanan bahan baku dan pencampuran bahan. Densitas bulk juga sangat penting dalam menentukan ukuran peralatan pencampuran. Dari hasil penelitian (tabel 3) menunjukkan bahwa semua formula memiliki densitas bulk yang lebih rendah dan dapat diasumsikan bahwa granul yang diperoleh memerlukan wadah yang kecil. 
Variasi ekstrak etanol biji alpukat (Persea americana Mill.) pada granul effervecsent sebagai antidiabetes

Sedangkan densitas mampat mirip dengan hasil densitas bulk.

\section{Indeks kompresibilitas (Carr's index)}

Suatu pengukuran propensitas serbuk untuk dapat dikempa. Indeks kompressibilitas ditentukan dari densitas bulk dan densitas mampat. Dalam teori, semakin kecil kemampuan dapat dikempa dari suatu bahan semakin dapat mengalir bahan tersebut. Kompresibilitas merupakan suatu pengukuran dari pentingnya interaksi antarpartikulat. Dalam serbuk yang bebas mengalir, interaksi tersebut pada umumnya tidak signifikan, dan densitas bulk dan densitas mampat akan lebih dekat nilainya. Untuk serbuk bahan yang sukar mengalir, terdapat ingteraksi antarpartikel yang lebih besar, dan semakin besar perbedaan antara densitas bulk dan densitas mampat akan teramati. Dari hasil penelitian diperoleh bahwa nilai indeks kompressibilitas dari semua formula (tabel 4) termasuk dalam nilai dengan sifat aliran granul yang memiliki kemampuan mengalir yang paling baik yaitu $5-15 \%{ }^{9}$ Rasio Hausner merupakan indeks tidak langsung dari kemudahan aliran serbuk. Dari hasil yang diperoleh (tabel 4) dapat lihat bahwa semua formula memiliki nilai Haussner's ratio kurang dari 1,25 ynag menunjukkan bahwa granul effervescent yang diperoleh mmemiliki aliran yang baik.

\section{Sudut Diam}

Sudut diam pada formula 1 dan 2 adalah $15.35^{\circ}$ dan $19.79^{\circ}$. nilai tersebut menunjukkan garnul memiliki aliran yang baik. Formula 2 adalah $19,79^{\circ}$ yang berarti bahwa granul dapat lewat tetapi memerlukan penambahan glidan. Rasio

hausner pada semua formula menunjukkan kurang dari 10 . Nilai tersebut berarti bahwa granul tersebut memiliki sifat aliran yang paling baik. Sedangkan Carr's Index dari semua formula mengindikasikan bahwa granul effervescent memiliki aliran yang sangat baik.

\section{Waktu alir dan kecepatan alir}

Waktu alir dan kecepatan alir granul effervescent dipengaruhi oleh gaya friksi antarpartikel. Waktu alir dan kecepatan alir di pengaruhi oleh besarnya sudut diam, indeks kompresibilitas dan Hausnerr's ratio. Semakin kecil sudut diam, semakin nilai indeks kompresibilitas dan nilai Hausnerr's rasio kurang dari 1,25 maka kecepatan alir granul baik. Kecepatan aliran granul mempengaruhi jumlah granul yang akan mengalir masuk kedalam wadah. Jumlah granul yang masuk kedalam wadah mempengaruhi jumlah dosis yang akan dikonsumsi oleh pasien.

\section{Waktu penghentian buih}

Waktu penghentian buih dari semua formula adalah 1.15 detik nilai tersebut berarti bahwa granul effervescent tidak memerlukan waktu untuk melarut di dalam air. Waktu yang lebih cepat untuk granul effervescent herbal ekstrak daun talas melarut di dlam air disebabkan karena reaksi dari asam sitrat dan asam tartarat dengan natrium bikarbonat dengan adanya air molekul air.

Berdasarkan hasil pengukuran kadar glukosa darah pada formula 1 dan formula 2 sediaan effervecsent ekstrak etanol biji alpukat dengan menggunakan konsentrasi 

antidiabetes

ekstrak sebesar $1 \%$ dan $10 \%$ menunjukkan bahwa formula 2 menunjukkan terjadinya penurunan kadar glukosa yang paling efektif berdasarkan pengamatan pada hari ke-1, ke3, ke-5 dan ke-7. Namun jika dibandingkan dengan kontrol obat menunjukkan bahwa obat akarbose menunjukkan penurunan kadar glukosa yang lebih effertif dikarenakan kadar senyawa yang terkandung dalam obat akarbose lebih murni dibandingkan dengan ekstrak pada kosentrasi $1 \%$ dan $10 \%$.

\section{KESIMPULAN}

Berdasarkan hasil penelitian dapa disimpulkan bahwa ekstrak etanol biji alpukat dapat dibuat menjadi granul effervescent dan mamiliki sifat fisika yang baik secara farmaseutik adalah pada formula 2 berdasarkan parameter densitas bulk $=2.82$, densitas mampat $=0.353$, carr's indeks $=$ 17.12, sudut diam $=19.79^{\circ}$, waktu alir $=0.7$ dan waktu penghentian buih $=1.15$. Hasil pengujian kadar glukosa darah dengan perbandingan variasi kosentrasi sediaan granul effervecsent menunjukkan bahwa yang paling efektif adalah pada formula 2 dengan menggunakan kosentrasi ekstrak 10\%.

\section{DAFTAR PUSTAKA}

1. Ramachandran, Ambady and Snehalata C. Diabetes Melitus. In: Gibney BJ, Margetts BM, Kearney JM \& Arab L. Gizi Kesehatan Masyarakat, diterjemahkan oleh Hartono A. Jakarta: EGC, 2009: 407408.
2. Wild S, Roglic G, Green A, Sicree R and King $H$. Global Prevalence of Diabetes: Estimates for year 2000 and Projections for 2030. Journal Diabetes Care 2004; $27(5): 47-53$.

3. World Health Organization (WHO). Department of Noncommunicable Disease Surveillance Geneva. Definition, Diagnosis and Classification of Diabetes Mellitus and its Complications. Report of a WHO Consultation Part 1 : Diagnosis and Classification of Diabetes Mellitus, 1999.

4. Muchid A. Pharmaceutical Care Untuk Penyakit Diabetes Mellitus. Jakarta: Direktorat Bina Farmasi Komunitas dan Klinik Direktorat Jenderal Bina Kefarmasian dan Alat Kesehatan Departemen Kesehatan Republik Indonesia, 2005:10-13.

5. Neal MJ. At a Glance Farmakologi Medis Edisi Kelima, Terjemahan Juwalita Surapsari, Penerbit Erlangga, PT Gelora Aksara Pratama, 2006:78.

6. Prihatman K. Budidaya Pertanian Alpukat (Persea americana Mill). Jakarta: Bappenas-Mengristekdikti, 2000:3.

7. Parikh DM. Handbook of Granulation Technology, 3rd Edition. New York: Informa Healthcare, 2010

8. Staniforth J. Powder flow In Pharmaceutics The Science of Dosage Form Design 2nd ed. Aulton ME. Scotland: Churchill Livingstone: Edinburgh, 2002.

9. Parrot EL. Pharmaceutical Tecnology Fundamental Pharmaceutitics.The Third Revision. Minneapois: Burgers Publishing Company, 1970. 